\title{
VERBAL FLUENCY TASK PERFORMANCE IN PERSONS WITH MODERATE INTELLECTUAL DISABLLITY'
}

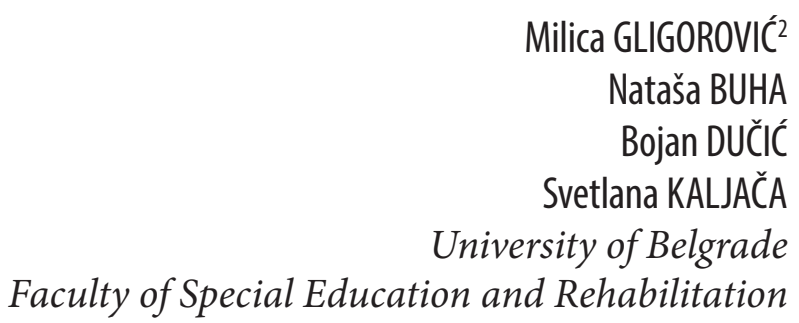

Verbal fluency is an indicator of the executive functions and mental lexicon. The aim of this paper is to determine phonemic and semantic productivity in persons with moderate intellectual disability (ID).

The sample consisted of 58 persons with moderate ID, aged 15-25. Phonemic fluency was assessed by the Controlled Oral Word Association Test, while the Category Naming Test (CNT) was used to assess semantic fluency.

The performance in the semantic fluency task was significantly better than the results on the phonemic fluency task. IQ was a significant factor of both assessed aspects of verbal fluency, but participants' age had a greater individual influence on semantic productivity and higher predictive value than IQ.

1 This paper is the result of the research project "Creating a protocol for assessing educational potentials of children with disabilities, as a criterion for the development of individual educational programs", ON 179025 (2011-2015), financed by the Ministry of Education, Science and Technological Development of the Republic of Serbia

2 E-mail: gligorovic@fasper.bg.ac.rs 
Specijalna edukacija i rehabilitacija (Beograd), Vol. 17, br. 3. 283-305, 2018.

We can conclude that maturation and experience represent significant factorsin forming lexical-semantic network, but they do not significantly contribute to the potential of persons with moderate ID for generating and using non-routine strategies. Intervention programs should offer a wider repertoire of strategies and more creative approach in strategy generation, organization and manipulation.

Key words: moderate intellectual disability, verbal fluency, phonemic fluency, semantic fluency, executive functions

\section{INTRODUCTION}

Problem solving is a cognitive-behavioural process which involves applying knowledge, skills and strategies in new situations. The repertoire, selection and use of strategies are considered to be crucial for higher levels of behavioural organization, which are the basis of learning and adaptive functioning (Borkowski \& Muthukrishna, 1992, according to Gligorović \& Buha, 2013).

Apart from mastering knowledge and skills much more slowly than typically developing population, persons with intellectual disability (ID) also usually have difficulties in generating and using strategies such as repetition, conceptualization (creating new ideas or relating a number of ideas to previous experience), generalization, organizing and monitoring activities (Bosson et al., 2010; Chung \& Tam, 2005; Joseph \& Konrad, 2009). These difficulties are manifested in problems with focusing on significant task dimensions, following several dimensions at the same time, neglecting irrelevant information, as well as relying on dimensions that were important for solving tasks in previous experience. This leads to limited possibilities to acquire new information (Buha \& Gligorović, 2012; Gligorović \& Buha, 2011). It is believed that information processing in persons with ID is less the result of a conscious, deliberate act than in typically developing persons, and that their behaviour in problem situations often seems automatic, unsystematic and disorganized (Gligorović \& Buha, 2013). 
One of the ways to assess strategy generation ability is by applying verbal fluency tasks. Verbal fluency is the production of as many words as possible (productivity score) in a limited period of time (usually one minute), starting with a specific phoneme (phonemic fluency) or a certain category (semantic fluency). Although the number of potential answers in phonemic fluency tasks is in theory much larger than the number of possible answers in semantic fluency tasks, the number of produced words from certain categories is larger than the number of produced words starting with a certain phoneme, both in typically developing adults (Kavé, 2005; Troyer, 2000), and children (Charchat-Fichman, Martins Oliveira, \& Morais da Silva, 2011; Kavé, 2006; Matute, Rosselli, Ardila, \& Morales, 2004; Riva, Nichelli, \& Devoti, 2000; Sauzeon, Lestage, Raboutet, N'Kaoua, \& Claverie, 2004). Identical pattern, but of different magnitude, is found in the population of children with mild ID (Danielsson, Henry, Messer, \& Ronnberg, 2012; Gligorović \& Buha, 2011), Down syndrome (Nash \& Snowling, 2008), ADHD (Abreu et al., 2013), and persons with autism (Turner, 1999).

Semantic fluency involves evoking information organized in hierarchically related clusters. Activating one of the clusters involves the production of responses until it is used up completely. After that, another group of associations is activated, i.e. words which belong to the same category. In forming clusters, most people do not use the initial phoneme of a specific word as a selection criterion, but organize information according to semantic categories. A similar approach is used in solving phonemic fluency tasks. Most people solve this task by searching for words starting with the given phoneme within the specific category, and then move on to the next one. With regard to the described strategies used for browsing the mental lexicon, although it seems less demanding, the phonemic fluency task actually comprises two demands - browsing according to both semantic and phonological characteristics of words (Azuma, 2004; Azuma et al., 1997). These two tasks correlate in the range from 0.30 to 0.50 (Charchat-Fichman et 
al, 2011; Kavé, 2005; Riva et al., 2000), which indicates the fact that they assess different but closely related processes.

Generating words according to a certain criterion in a limited time period requires guided behaviour. These procedural limitations in both tasksrequire attention and fast information processing, as well as strategic planning, which involves generating and using an appropriate strategy to browse the mental lexicon, flexibility of thinking, and monitoring the performance for the purpose of controlling mistakes (within a specific criterion, the participant has to inhibit irrelevant associations and be aware of already produced words in order to avoid their repetition) (Azuma, 2004; Bittner \& Crowe, 2007; Gligorović \& Buha, 2014; Rende, Ramsberger, \& Miyake, 2002). Although factor analysis determined that semantic and phonemic fluency are grouped in one factor together with the naming ability, the presence of two different types of variance is observed, one which reflects general language development, and the other which reflects individual differences specifically related to phonemic fluency, independent from semantic fluency and naming in total (Riva et al., 2000). Unlike semantic fluency, which relies on the approach to semantic memory and automatic activation of semantic relations, phonemic fluency depends more on the ability to browse the mental lexicon in an organized way. By analyzing the influence of basic executive functions (EFs) on the development of verbal fluency in children with mild ID, it was determined that difficulties in strategic browsing are the basis of the difference between phonemic and semantic fluency. These difficulties are directly related to the developmental level of cognitive flexibility, working memory, and inhibitory control (Gligorović \& Buha, 2014). In the population of children with Down syndrome, it was determined that, unlike semantic fluency, phonemic fluency is not significantly related to vocabulary, and that linguistic representations of these children are equally rich and extensive as those of typically developing children of the same verbal age (Nash \& Snowling, 2008).Vocabulary scope and the speed of approaching mental lexicon are significant determinants 
of semantic,rather than phonemic, fluency in older typically developing adults as well (Shao et al., 2014). Thus, by comparing the performance in these two tasks, we can get an insight into how participants' semantic system is organized and whether the participants are able to independently generate a strategy which will make evoking lexical items easier.

These two tasks have different developmental dynamics. In early childhood, abrupt and dynamic changes happen in semantic fluency, the development of which becomes more linear at the age of 12-13. Developmental changes in phonemic fluency are slower and last until late adolescence and/or early adulthood (Kavé, 2006; Sauzeon et al., 2004). The discrepancy between these two tasks is present throughout the entire life of healthy persons. By analyzing the results of different studies (e.g., Kavé, 2006; Matute et al., 2004; Nash \& Snowling, 2008) it is observed that in early childhood the productivity in semantic fluency is double than the productivity in phonemic fluency, while this difference is reduced to almost a third in adolescence and adulthood. Thus, significantly lower productivity in phonemic fluency tasks than in semanticfluency tasks indicates the presence of difficulties in strategic evoking of words (and in a wider sense, executive functions) (Abreu et al., 2013; Banerjee, Grange, Steiner, \& White, 2011; Hernandez et al., 2002).

The aim of this paper is to determine verbal fluency performanceand relation between phonemic and semantic productivity in persons with moderate intellectual disability.

\section{METHOD}

\section{Participants}

The sample consisted of 58 persons with moderate ID (IQ 35-50, $M=42.12, S D=3.857$, diagnosed according to ICD-10), of both genders, aged between 15 and $25(M=19.67$; $S D=3.42)$. Only participants who lived in an institutionfor people with 
intellectual disability in Belgrade were selected in order to avoid potential performance differences caused by environmental factors. The participants were divided in two groups with regard to age. There were 31 (53.4\%) participants aged between 15 and 18 in the first group, and 27 (46.6\%) participants aged between 18.11 and 25 in the second group. The distribution of IQ score made it possible to divide the sample on the basis of intellectual abilities as follows: the group with lower IQ $(\leq 40)$ consisting of $33(56.9 \%)$ participants, and the group with higher IQ $(\geq 41)$ consisting of 25 (43.1\%) participants. The sample included 20 (34.5\%) participants with dual diagnoses (DD), ID and behavioural problems. There was no information on the type and severity of the disorder in the available documentation. The presence of DD was not statistically significantly related to age $(\rho=0.200, p=0.173)$, gender $(\rho=-0.016, p=0.914)$, and IQ $(\rho=-0.088, p=0.554)$. No statistically significant relation was determined between IQ and the participants' age $(r=0.051$, $p=0.736)$ and gender $(\rho=-0.079, p=0.594)$.

\section{Instruments and procedure}

Data on age, medical history, and the results of standard psychometric instruments (IQ) were gathered by analyzing official documentation.

Verbal fluency assessment was conducted by applying tests of phonemic and semantic fluency. For the purpose of this research, productivity score (the total number of correct answers/words in a given time frame) was used in both tests as the main variable. The assessment was conducted individually, in a secluded room. Permission to conduct assessment in institutions was obtained from the social services prior to assessment.

Phonemic fluency was assessed by the adapted version of the Controlled Oral Word Association Test - COWAT (Benton, 1968, according to Lezak, Howieson, \& Loring, 2004). Phonemes which are most frequent in English speaking 
countries $-F, A$, and $S$ are used in the original version, which is why the test is also popularly called FAS (Lezak et al., 2004). The corresponding phonemes in Serbian are $K, M$, and $S$ (Lukić, 1983), and were thus used as phonemic indicators. The participants were required to list as many different words (nouns) as possible starting with a given phoneme in a certain time period (60s for each phoneme/indicator), excluding proper nouns, place names, numbers, and same words with different suffixes. Phonemic productivity score was obtained by summing up the correct answers for all three given phonemic indicators.

Semantic fluency was assessed by the adapted version of the Category Naming Test - CNT (Welsh et al., 1991). When compared to the original version, the test excluded things to ride category, and the time period for giving answers was longer (60s instead of 40s). Categories including food, clothes and animals were defined as semantic indicators. The participants' task was to list as many different words as possible from a given category in the given time period (60s for each category/indicator). Semantic productivity score was obtained by summing up the correct answers/words for all three given semantic indicators.

\section{Data analysis}

Central tendency measures, variability measures and the results range were used for presenting basic statistical indicators, while parametric and non-parametric correlation coefficient, t-test, one-way analysis of variance (ANOVA), and multiple regression were used to determine the significance of the relation between the observed variables. 
Specijalna edukacija i rehabilitacija (Beograd), Vol. 17, br. 3. 283-305, 2018.

RESULTS

The results of phonemic and semantic fluency assessment are presented as productivity scores, which represent the sum of scores (number of correct words/answers) obtained for each of the given phonemic (phonemes $K, M$, and $S$ ) and semantic (food, clothes, and animals) indicators.

Table 1 - Basic statistical characteristics of the results of phonemic and semantic fluency assessment

\begin{tabular}{lcccc}
\hline Verbal fluency & Min & Max & Mean & SD \\
\hline Phonemic productivity score & 0 & 21 & 4.15 & 5.43 \\
\hline Semantic productivity score & 3 & 46 & 22.44 & 9.82 \\
\hline
\end{tabular}

The participants with moderate ID weremuch more successful in the test which assessed semantic fluency (Table 1). A highly significant difference in productivity scores was determined in the tasks which assessed phonemic and semantic fluency $(t(57)=-15.436, p \leq 0.000 r=0.549, p \leq 0.000)$. On the basis of percentile ranks, phonemic and semantic productivity scores were grouped in three categories - up to $25^{\text {th }}$ percentile (low results), $50^{\text {th }}-75^{\text {th }}$ percentile (average results), and above $75^{\text {th }}$ percentile (the best results). Most participants (75.9\%) produced up to two words in phonemic fluency test (41.1\% none - up to $25^{\text {th }}$ percentile, and $34.5 \%$ one to two words - from $25^{\text {th }}$ to $75^{\text {th }}$ percentile), while they weremuch more successful in the CNT since $72.4 \%$ of the participants managed to produce at least 17 words, with $48.3 \%$ of the participants producing from 17 to 21 words $\left(25^{\text {th }}-75^{\text {th }}\right.$ percentile), and $24.1 \%$ from 22 to 29 words (above $75^{\text {th }}$ percentile) according to the given semantic indicators (more detailed in graphs 1 and 2). 


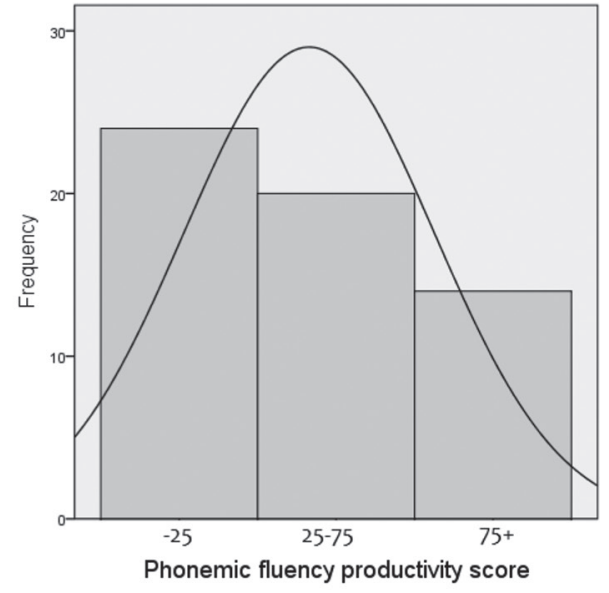

Figure 1 - Percentile ranks of COWAT results

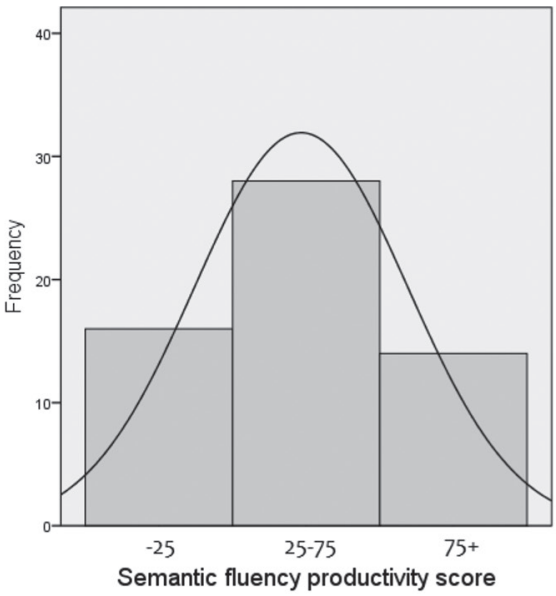

Figure 2 - Percentile ranks of CNT results

\section{Gender, age, IQ and dual diagnoses as verbal fluency factors in people with moderate ID}

No statistically significant differences of COWAT results were determined between the participants of different age and gender. Also, the presence of dual diagnoses had no statistically significant influence on the results. Table 2 shows the correlation between the productivity scores of verbal fluency (phonemic and semantic) with the participants' IQ and age.

Table 2 - Correlation between phonemic and semantic fluency and the participants' IQ and age

\begin{tabular}{|c|c|c|c|}
\hline \multirow{4}{*}{ Phonemic productivity score } & \multirow{2}{*}{ IQ } & $r$ & 0.524 \\
\hline & & $p$ & 0.000 \\
\hline & \multirow{2}{*}{ Age } & $r$ & 0.241 \\
\hline & & $p$ & 0.099 \\
\hline \multirow{4}{*}{ Semantic productivity score } & \multirow{2}{*}{ IQ } & $r$ & 0.518 \\
\hline & & $\mathrm{p}$ & 0.000 \\
\hline & \multirow{2}{*}{ Age } & $r$ & 0.512 \\
\hline & & $\mathrm{p}$ & 0.000 \\
\hline
\end{tabular}

Statistically significant values are marked (bold). 
Specijalna edukacija i rehabilitacija (Beograd), Vol. 17, br. 3. 283-305, 2018.

A significant relation was determined between IQ and productivity scores in both assessed domains of verbal fluency, while the participants' age was significantly related to the CNT results, i.e. with semantic productivity score.

Variance analysis determined that IQ was a significant factor of both assessed aspects of verbal fluency, the influence of which can explain a quarter of COWAT results variance and a bit more than $13 \%$ of CNT results variance (more detailed in Table 3). The participants who belonged to the group with a lower IQ achieved significantly lower scores of phonemic and semantic productivity.

Table 3 - The influence of IQ and age on phonemic and semantic productivity of people with ID

\begin{tabular}{|c|c|c|c|c|c|c|c|}
\hline Factor & VF & IQ & Mean & SD & $F$ & $p$ & $\eta_{\text {part }}^{2}$ \\
\hline \multirow{4}{*}{ IQ } & \multirow{2}{*}{ PPS } & $\leq 40$ & 1.78 & 2.58 & \multirow{2}{*}{15.309} & \multirow{2}{*}{0.000} & \multirow{2}{*}{0.250} \\
\hline & & $\geq 41$ & 7.19 & 6.59 & & & \\
\hline & \multirow{2}{*}{ SPS } & $\leq 40$ & 19.30 & 8.13 & \multirow{2}{*}{7.141} & \multirow{2}{*}{0.010} & \multirow{2}{*}{0.134} \\
\hline & & $\geq 41$ & 26.48 & 10.5 & & & \\
\hline \multirow{2}{*}{ Age } & \multirow{2}{*}{ SPS } & $\leq 18$ & 17.62 & 6.82 & \multirow{2}{*}{18.886} & \multirow{2}{*}{0.000} & \multirow{2}{*}{0.291} \\
\hline & & $\geq 19$ & 28.14 & 9.88 & & & \\
\hline
\end{tabular}

VF - Verbal fluency; PPS - Phonemic productivity score; SPS - Semantic productivity score. Statistically significant values are marked (bold).

By analyzing the relation between age and the results of verbal fluency tests, it was determined that semantic productivity scores of older participants ( $\geq 19$ years of age) were significantly higher $(\mathrm{p} \leq 0.000)$ than the scores of the younger group. The participants' age can explain almost 30\% of CNT results variability (more detailed in Table 3). No statistically significant relation was determined between the participants' age and the results of phonemic fluency assessment.

By applying multiple regression, it was determined that participants' age had a greater influence on semantic productivity score and a higher predictive value $(\beta=0.461)$ than IQ $(\beta=0.228)$. Both analyzed independent variables had a statistically significant individual influenceon semantic productivity score (more detailed in Table 4). 
Table 4 - The participants' IQ and age as semantic fluency factors: the results of multiple regression analysis

\begin{tabular}{lcccccccc}
\hline SPS & $F(1)$ & $p$ & $R^{2}$ & $R^{2}{ }_{\text {Adiust }}$ & $\beta_{\text {stand }}$ & part & $t(57)$ & $p$ \\
\hline Age & 18.730 & $\mathbf{0 . 0 0 0}$ & 0.251 & 0.237 & 0.461 & 0.454 & 4.025 & $\mathbf{0 . 0 0 0}$ \\
\hline IQ & 3.998 & $\mathbf{0 . 0 5 0}$ & 0.050 & 0.050 & 0.228 & 0.225 & 1.998 & 0.050 \\
\hline Age and IQ & 11.849 & $\mathbf{0 . 0 0 0}$ & 0.301 & 0.276 & $/$ & $/$ & -4.286 & $\mathbf{0 . 0 0 0}$ \\
\hline
\end{tabular}

SPS - Semantic productivity score. Statistically significant values are marked (bold).

\section{DISCUSSION}

In the COWAT, which assesses phonemic fluency, persons with moderate ID produced the average of 4 (4.15) words for all three given phonemes together, which is a considerably lower average productivity score from the one in typically developing school-age children, who produce between 26 and 30 words for all three given phonemes (Levin, Culhane, Hartmann, Evankovich, \& Mattson, 1991; Strauss, Sherman, \& Spreen, 2006), and school-age children with mild ID (11-14 words on average) (Danielsson et al., 2012; Gligorović \& Buha, 2011, 2014).

In the test which assesses semantic fluency (categories: animals, food, and clothes) the participants with moderate ID listed the average of 7 words per category. The average semantic productivity score is lower than that of school-age children with mild ID (the average of 10-12 words per category) (Danielsson et al., 2012; Gligorović \& Buha, 2011), and typically developing children (about 18 words per category) (Levin et al., 1991; Strauss et al., 2006).

The correlation between the scores of phonemic and semantic productivity is within themoderate range $(r=0.549)$, which confirms the findings of studies conducted in the population of typically developing persons (children and adults) (Charchat-Fichman et al., 2011; Kavé, 2005; Riva et al., 2000).

By analyzing mean values of phonemic and semantic productivity scores in persons with moderate ID, it was determined that the participants achieved significantly 
Specijalna edukacija i rehabilitacija (Beograd), Vol. 17, br. 3. 283-305, 2018.

lower scores in the COWAT, which assesses phonemic fluency $(p \leq 0.000)$. The difference in phonemic and semantic productivity is also present in typically developing children (Koren \& Kofman, 2005; Riva, Nichelli, \& Devoti, 2000; Sauzeon et al., 2004; Tallberg, Carlsson, \& Lieberman, 2011) and adults (Mimica et al., 2011; Troyer, 2000), as well as in children with mild ID (Gligorović \& Buha, 2011, 2014). However, the scope of this difference is significantly smaller comparing to persons with moderate ID. Phonemic productivity score in typically developing children equals half of the semantic productivity score, one third in children with mild ID, while in the participants with moderate ID, the performance in phonemic fluency test (COWAT) is more than five times (5.41) lower than their performance in semantic fluency test (CNT). Phonemic fluency is more related to engaging executive functions than semantic fluency.Thus, the obtained results can be considered a clear indicator of difficulties in generating and using the strategy in persons with moderate ID. Semantic fluency primarily relies on linguistic representation, common and empirically well-established strategies of grouping lexical items into meaningful systems (categories), while phonemic fluency means generating and using less common, nonroutine strategies and more significant activation of executive control (Strauss et al., 2006). Words are usually taxonomically organized in the lexical system, and browsing according to phonemic indicators requires a flexible alteration of the usual approach and the inhibition of irrelevant answers, which often represents a difficulty for persons with ID (Danielsson, Henry, Rönnberg, \& Nilsson, 2010; Gligorović \& Buha Đurović, 2014; Merrill \& Taube, 1996; Numminen et al., 2000).Thus, their performance is worse than expected with regard to mental age (Danielsson et al., 2012).

No statistically significant differences of COWAT results were determined between the participants of different ages. Similar finding was obtained in thestudy which included children with mild ID aged between 10 and 14 (Gligorović \& Buha, 2011). The absence of age-based differences in phonemic 
fluency can be the result of reaching the developmental plateau of browsing verbal strategies earlier, but it can also result from rigidly organized knowledge, i.e. favoring taxonomic approach in the process of education. This is supported by significantly better results of the participants in the CNT and a significant influence $(\mathrm{p} \leq 0.000)$ of age (experience and practice), which explains almost $30 \%$ of the variance, on semantic productivity score. There is no definite agreement regarding the dynamics of verbal fluency development in typically developing persons.Thus, some authors believe it lasts until the age of 10-11 (Anderson et al. 2001, according to Matute et al., 2004), others believe it lasts at least to the age of 13 (Kavé, Kigel, \& Kochva, 2008), while some studies report on the development of fluency in adolescence and early adulthood (Matute et al., 2004; Tallberg et al., 2011).However, phonemic productivity score in children with mild ID and younger persons with moderate ID indicates a clear differentiation of phonemic and semantic fluency. Semantic fluency primarily relies on lexical knowledge and practicing browsing strategies. Thus, semantic productivity score primarily points to most frequently used taxonomic organization of lexical-semantic network. In solving phonemic and semantic fluency tasks, clustering within categories is activated first, which involves applying a specific grouping strategy (according to the indicator type), and finding appropriate members of the given category which are organized in subcategories (Raboutet et al., 2010). Two types of forming subcategories are used in phonemic approach (according to the same first two phonemes and rhyme) (Troyer, 2000), while different, more or less conventional approaches of forming subcategories can be used in semantic categorization of words (Crowe \& Prescott, 2003, according to Nash \& Snowling, 2008). Switching from one formed subcategory to the other is an inter-category process which is based on the processes of strategic browsing, cognitive flexibility and shifting, and requires a more active engagement of EFs. The number of formed clusters reflects the application of the browsing strategy, and the size of clusters depends on 
the content (vocabulary) and organization of lexical-semantic memory. A stronger inclination to conventional, most frequently taxonomic, categorization of wordsoccurs with age (Raboutet et al., 2010), which in persons with ID, whose choice of strategies is limited, can lead to a rigid usage of well-practiced approaches and difficulties in transferring to new approaches in tasks solving. Bearing in mind that phonemic fluency tasks require the application of non-routine approaches to clustering and overcoming a semantic distance between phonemic indicators, it can be assumed that low phonemic productivity scores, independently of the participants' age, in persons with moderate ID are based primarily on the difficulties in EFs. According to the results of our previous study, the influence of EFs explains about $40 \%$ of phonemic productivity score variance, and about $10 \%$ of semantic productivity score variance in children with mild ID, with cognitive flexibility (assessed by WCST and TMT-B) having the greatest influence on the total variance of phonemic productivity score. The role of cognitive flexibility in phonemic fluency tasks is manifestedin the process of conceptualization (forming the principle of categorization) and shifting from one to another selection principle (Gligorović \& Buha, 2014). Bearing in mind that verbal and non-verbal fluency can also be observed as an aspect of spontaneous flexibility (Ebersbach \& Hagedorn, 2011), the relation between verbal productivity scores and the achievement in WCST and TMT-B is not surprising. Working memory and inhibitory control have somewhat smaller, but still statistically significant, influence on the results variability. A significant influence of cognitive flexibility is also present in the process of semantic categorization. However, this influence is significantly smaller than the onein phonemic categorization, while the influence of working memory and inhibitory control was not confirmed (Gligorović \& Buha, 2014).

Variance analysis determined a significant influence $(\mathrm{p} \leq 0.000)$ of IQ on phonemic productivity score in the participants with moderate ID, which explains a quarter (25\%) of COWAT results variance, and on semantic productivity 
score (13.4\% of variance). In children with mild ID, IQ has a less significant influence on verbal fluency and independently explains $11.6 \%$ of COWAT results variability, and about $6 \%$ of CNT variance (Gligorović \& Buha, 2014). A significant influence of IQ on verbal fluency in both assessed domains is expected if we consider the fact that verbal productivity, or fluency, has traditionally been considered either as a factor of verbal intelligence or as a creativity index, especially in younger chronological (or mental) ages. The relation between fluency and intelligence is much less expressed in adults, and is manifested primarily in younger adults and persons older than 60 (Ardila, Pineda, \& Rosselli, 2000).

In the domain of semantic productivity, apart from IQ, a significant influence of age (29.1\% of variance) on CNT results was determined. By applying multiple regression, it was determined that, even though both analyzed independent variables statistically significantly influence semantic productivity score, the participants' age has a greater individual influence $(p \leq 0.000)$, and a greater predictive value $(\beta=0.461)$ than IQ $(\beta=0.228)$.

This finding actually confirms the significance of experience in enriching and establishing a lexical-semantic network in persons with ID. In persons with moderate ID, intentional or incidental acquisition of strategies by observation and repetition is usually inevitable. This means that a person observes and imitates the behaviour of others, not taking part in the creation of strategies (Lyon, Fletcher, Fuchs, \& Chhabra, 2006).

This research also confirmed that persons with moderate ID almost exclusively incline to routine approaches and contents which are the closest to their everyday experience. The participants with moderate ID primarily rely on context and the selection of words they use every day in different activities. For example, in listing words in the food category, they most frequently produced words which described the food from the menu of the institution they lived in, in the animals category 
they first listed domestic animals bred on the farm of the institution they lived in, etc. Grouping with regard to context is predominant in food and animalscategories in the research on semantic fluency in persons with Down syndrome (Nash \& Snowling, 2008).

Lower phonemic and semantic productivity can be the consequences of insufficient knowledge of the concepts (which belong to the given categories), poorly organized knowledge or inefficient strategy for linking words. The results of our research indicate that the participants with moderate ID who live in an institution much more successfully use routine than non-routine strategies, and that the difficulties in phonemic fluency are primarily related to the level of intellectual abilities, the application of inadequate strategies, or lack of strategy. The difficulties in applying non-routine strategies are primarily related to EFs.However, the influence of environmental factors, such as high level of external control and tendency to overprotect persons with disability should not be ignored (Maier, Peterson, \& Schwartz, 2000; Peterson, Maier, \& Seligman, 1993; Sanders, 2006).

Apart from the obvious difference in intellectual abilities when compared to typically developing persons and persons with mild ID, lower semantic productivity could be explained by inadequate vocabulary and category knowledge, just as in typically developing persons (Sauzeon et al., 2004) and persons with mild ID (Gligorović \& Buha, 2011).

\section{Limitations}

In order to gain a clearer insight into generation and usage of browsing strategies according to e.g. Troyer's (2000) criteria, analysis of the number, size, and content of clusters should be performed, which was not possible in this research. The number and/or content of correct answers in phonemic fluency task was not enough for forming subcategories (clusters). Also, semantic fluency test performance was dominated by the 
presence of a single cluster formed according to the thematic (contextual) principle, while in other produced words, if there were any, none of the categorization principles were observed. The sample consisted only of the participants with moderate ID who lived in an institution, which significantly limits the possibility to generalize the obtained results. Such selection criterion resulted from the inability to equalize the initial, more numerous sample with regard to relevant socio-demographic parameters (type of residence, socio-economic status, family status, parents' education level, etc.).

\section{CONCLUSION}

Phonemic and semantic productivity score in persons with moderate ID aged between 15 and 25, who live in an institution, is considerably lower than average scores in verbal fluency tasks in typically developing persons and persons with mild ID. Apart from that, the discrepancy between phonemic and semantic flexibility is significantly higher (semantic productivity is more than five times better than phonemic productivity) than in typically developing persons and persons with mild ID.This indicates the existence of difficulties in generating and using strategies in these persons. With regard to the fact that statistically significant influence of IQ on phonemic fluency was determined, but that the influence of the participants' age was not, it could be said that unlike semantic productivity which improves with age, maturation and experience are not significant factors of the potential for strategy generation. Although both intelligence and age proved to be significant factors of semantic fluency, a more detailed analysis has shown that the participants' age has a greater individual influence and a greater predictive value than IQ.

By summing up the results, we can conclude that maturation and experience represent a significant factor in forming lexical-semantic network. However, they do not considerably contribute to the potential of persons with 
Specijalna edukacija i rehabilitacija (Beograd), Vol. 17, br. 3. 283-305, 2018.

moderate ID to generate and use non-routine strategies, which are primarily based on EFs. This implicitly means that if the intervention programs do not offer a wider repertoire of strategies, these persons will exclusively rely on routine, almost automatic procedures which enable the enrichment of conceptual system based on conventional, taxonomic principle. Intervention should offer a wider repertoire of strategies andmore creative approach in strategy generation, organization and manipulation.

\section{REFERENCES}

1. Abreu, N., Argollo, N., Oliveira, F., Cardoso, A. L., Bueno, J. L. O., \& Xavier, G. F. (2013). Semantic and phonologic verbal fluency tests for adolescents with ADHD. Clinical Neuropsychiatry, 10(2), 63-71.

2. Ardila, A., Pineda, D., \& Rosselli (2000). Correlation between intelligence test scores and executive function measures. Archives of Clinical Neuropsychology, 15(1), 31-36. doi:10.1093/arclin/15.1.31

3. Azuma, T. (2004). Working memory and perseveration in verbal fluency. Neuropsychology, 18(1), 69-77. doi:10.1037/0894-4105.18.1.69

4. Azuma, T., Bayles, K. A., Cruz, R. F., Tomoeda, C. K., Wood, J. A., McGeagh, A., et al. (1997). Comparing the difficulty of letter, semantic, and name fluency tasks for normal elderly and patients with Parkinson's disease. Neuropsychology, 11(4), 488-497. doi:10.1037//0894-4105.11.4.488

5. Banerjee, P.,Grange, D. K., Steiner, R. D., \& White, D. A. (2011). Executive strategic processing during verbal fluency performance in children with phenylketonuria. Child Neuropsychology, 17(2), 105-117. doi:10.1080/09297049.2010.525502

6. Bittner, R. M., \& Crowe, S. F. (2007). The relationship between working memory, processing speed, verbal comprehension and FAS performance following traumatic brain injury. Brain Injury, 21(7), 709-719. doi:10.1080/02699050701468917

7. Bosson, M. S., Hessels, M. G. P., Hessels-Schlatter, C., Berger, J. L., Kipfer,N. M., \& Büchel, F. P. (2010). Strategy acquisition by children with general learning difficulties through metacognitive 
training. Australian Journal of Learning Difficulties, 15(1), 13-34. doi:10.1080/19404150903524523

8. Buha, N., \& Gligorović, M., (2012). Sposobnost planiranja kod dece sa lakom intelektualnom ometenošću. Specijalna edukacija $i$ rehabilitacija, 11(3), 365-382. doi:10.5937/specedreh11-2320

9. Cerhan, J. H., Ivnik, R. J., Smith, G. E., Tangalos, E. C., Petersen, R. C., \& Boeve, B. F. (2002). Diagnostic utility of letter fluency, category fluency, and fluency difference scores in Alzheimer's disease. The Clinical Neuropsychologist, 16(1), 35-42. doi:10.1076/ clin.16.1.35.8326

10. Charchat-Fichman, H., Martins Oliveira, R. M., \& Morais da Silva, A. M. D. (2011). Performance of Brazilian children onphonemic and semantic verbal fluency tasks. Dementia \& Neuropsychologia, 5(2), 78-84. doi:10.1590/s1980-57642011dn05020004

11. Chung, K. K. H., \& Tam, Y. H. (2005). Effects of cognitive-based instruction on mathematical problem solving bylearners with mild intellectual disabilities. Journal of Intellectual \& Developmental Disability, 30(4), 207-216. doi:10.1080/13668250500349409

12. Danielsson, H., Henry, L., Rönnberg, J., \& Nilsson, L. G. (2010). Executive functions in individuals with intellectual disability. Research in Developmental Disabilities, 31(6), 1299-1304. doi:10.1016/j.ridd.2010.07.012

13. Danielsson, H., Henry, L., Messer, D., \& Rönnberg, J. (2012). Strengths and weaknesses in executive functioning in children with intellectual disability. Research in Developmental Disabilities, 33(2), 600-607. doi:10.1016/j.ridd.2011.11.004

14. Ebersbach, M., \& Hagedorn, H. (2011). The role of cognitive flexibility in the spatial representation of children's drawings. Journal of Cognition and Development, 12(1), 32-55. doi:10.1080/ 15248372.2011.539526

15. Gligorović, M., \& Buha, N. (2011). Verbalna fluentnost kod dece sa lakom intelektualnom ometenošću. Specijalna edukacija $i$ rehabilitacija, 10(4), 595-612.

16. Gligorović, M., \& Buha, N. (2013). Verbalne strategije rešavanja problema kod dece sa lakom intelektualnom ometenošću. Specijalna edukacija i rehabilitacija, 12(1), 11-23. doi:10.5937/specedreh12-3333

17. Gligorović, M., \& Buha Đurović, N. (2014). Inhibitory control and adaptive behaviour in children with mild intellectual disability. 
Specijalna edukacija i rehabilitacija (Beograd), Vol. 17, br. 3. 283-305, 2018.

Journal of Intellectual Disability Research, 58(3), 233-242. doi:10.1111/jir.12000

18. Gligorović, M., \& Buha, N. (2014). Verbal fluency in children with intellectual disability: influence of basic executive components. Specijalna edukacija i rehabilitacija, 13(3), 275-292. doi:10.5937/ specedreh13-6829

19. Hernandez, M. T., Sauerwein, H. C., Jambaqué, I., De Guise, E., Lussier, F., Lortie, A., \& et al. (2002). Deficits in executive functions and motor coordination in children with frontal lobe epilepsy. Neuropsychologia, 40(4), 384-400. doi:10.1016/s0028-3932(01)00130-0

20. Joseph, L. M., \& Konrad, M. (2009). Teaching students with intellectual or developmental disabilities to write: A review of the literature. Research in Developmental Disabilities, 30(1), 1-19. doi:10.1016/j.ridd.2008.01.001

21. Kavé, G. (2005). Phonemic fluency, semantic fluency, and difference scores: normative data for adult Hebrew speakers. Journal of Clinical and Experimental Neuropsychology, 27(6), 690-699. doi:10.1080/13803390490918499

22. Kavé, G. (2006). The development of naming and word fluency: evidence from Hebrew-speaking children between ages 8 and 17. Developmental Neuropsychology, 29(3), 493-508. doi:10.1207/s15326942dn2903_7

23. Kavé, G., Kigel, S., \& Kochva, R. (2008). Switching and clustering in verbal fluency tasks throughout childhood. Journal of Clinical and Experimental Neuropsychology, 30(3), 349-359. doi:10.1080/13803390701416197

24. Koren, R., Kofman, O., \& Berger, A. (2005). Analysis of word clustering in verbal fluency of school-aged children. Archives of Clinical Neuropsychology, 20(8), 1087-1104. doi:10.1016/j.acn.2005.06.012

25. Levin, H. S., Culhane, K. A., Hartmann, J., Evankovich, K., Mattson, A. J., Harward, H., ... \& Fletcher, J. M. (1991). Developmental changes in performance on tests of purported frontal lobe functioning. Developmental Neuropsychology, 7(3), 377-395. doi:10.1080/87565649109540499

26. Lezak, M. D., Howieson, D. B., \& Loring, D. W. (2004). Neuropsychological Assessment, $4^{\text {th }}$ ed. New York: Oxford University Press. 
27. Lukić, V. (1983). Dečji frekvencijski rečnik. Beograd: Prosveta.

28. Lyon, G. R., Fletcher, J. M., Fuchs, L. S., \& Chhabra, V. (2006). Learning Disabilities. In E. J. Mash \& R. Barkley (Eds.), Treatment of Childhood Disorders, $3^{\text {rd }}$ ed. (pp. 512-594). Hillsdale, NJ: Erlbaum.

29. Maier, S. F., Peterson, C., \& Schwartz, B. (2000). From helplessness to hope: the seminal career of Martin Seligman. In J. E. Gillham (Ed.), The Science of Optimism and Hope (pp. 11-37). Radnor, PA: Templeton foundation press.

30. Matute, E., Rosselli, M., Ardila, A., \& Morales, G. (2004). Verbaland nonverbal fluency in Spanish-speaking children. Developmental Neuropsychology, 26(2), 647-660. doi:10.1207/s15326942dn2602_7

31. Merrill, E. C., \& Taube, M. (1996). Negative priming and mental retardation: the processing of distractor information. American Journal on Mental Retardation, 101(1), 63-71.

32. Mimica, N., Žakić Milas, D., Joka, S., Kalinić, D., Folnegović Šmalc, V., \& Harrison, J.E. (2011). A validation study of appropriate phonological verbal fluency stimulus letters for use with Croatian speaking individuals. Collegium Antropologicum, 35(1), 235-238.

33. Nash, H. M., \& Snowling, M. J. (2008). Semantic and phonological fluency in children with Down syndrome: Atypical organization of language or less efficient retrieval strategies?. Cognitive Neuropsychology, 25(5), 690-703. doi:10.1080/02643290802274064

34. Numminen, H., Service, E., Ahonen, T., Korhonen, T., Tolvanen, A., Patja, K., \& Ruoppila, I. (2000). Working memory structure and intellectual disability. Journal of intellectual Disability research, 44(5), 579-590. doi:10.1046/j.1365-2788.2000.00279.x

35. Peterson, C., Maier, S. F., \& Seligman, M. E. P. (1993). Learned Helplessness: A Theory for the Age of Control. New York, NY: Oxford University Press.

36. Raboutet, C., Sauzéon, H., Corsini, M. M., Rodrigues, J., Langevin, S., \& N'Kaoua, B. (2010). Performance on a semantic verbal fluency task across time: Dissociation between clustering, switching, and categorical exploitation processes. Journal of Clinical and Experimental Neuropsychology, 32(3), 268-280. doi:10.1080/13803390902984464

37. Rende, B., Ramsberger, G., \& Miyake, A. (2002). Commonalities and differences in the working memory components underlying 
Specijalna edukacija i rehabilitacija (Beograd), Vol. 17, br. 3. 283-305, 2018.

letter and category fluency tasks: A dual-task investigation. Neuropsychology, 16(3), 309-321. doi:10.1037//0894-4105.16.3.309

38. Riva, D., Nichelli, F., \& Devoti, M. (2000). Developmental aspects of verbal fluency and confrontation naming in children. Brain and Language, 71(2), 267-284. doi:10.1006/brln.1999.2166

39. Sanders, K. Y. (2006). Overprotection and lowered expectations of persons with disabilities: The unforeseen consequences. Work: $A$ Journal of Prevention, Assessment and Rehabilitation, 27(2), 181-188.

40. Sauzéon, H., Lestage, P., Raboutet, C., N'Kaoua, B., \& Claverie, B. (2004). Verbal fluency output in children aged 7-16 as a function of the production criterion: Qualitative analysis of clustering, switching processes, and semantic network exploitation. Brain and Language, 89(1), 192-202. doi:10.1016/s0093-934x(03)00367-5

41. Shao, Z., Janse, E., Visser, K., \& Meyer, A. S. (2014). What do verbal fluency tasks measure? Predictors of verbal fluency performance in older adults. Frontiers in Psychology, 5, 772. doi:10.3389/fpsyg.2014.00772

42. Strauss, E., Sherman, E. M. S., \& Spreen, O. (2006). A Compendium of Neuropsychological Tests: Administration, Norms and Commentary (3rd. ed.). New York: Oxford University Press.

43. Tallberg, I. M., Carlsson, S., \& Lieberman, M. (2010). Children's word fluency strategies. Scandinavian Journal of Psychology, 52(1), 35-42. doi:10.1111/j.1467-9450.2010.00842.x

44. Troyer, A. K. (2000). Normative data for clustering and switching on verbal fluency tasks. Journal of Clinical and Experimental Neuropsychology, 22(3), 370-378. doi:10.1076/13803395(200006)22:3;1-v;ft370

45. Turner, M. A. (1999). Generating novel ideas: Fluency performance in high-functioning and learning disabled individuals with autism. Journal of Child Psychology and Psychiatry, 40(2), 189-201. doi:10.1111/1469-7610.00432

46. Welsh, M. C., Pennington, B. F., \& Groisser, D. B. (1991). A normative-developmental study of executive function: A window on prefrontal function in children. Developmental Neuropsychology, 7(2), 131-149. doi:10.1080/87565649109540483 


\title{
POSTIGNUĆE OSOBA SA UMERENOM INTELEKTUALNOM OMETENOŠĆU NA ZADACIMA VERBALNE FLUENTNOSTI
}

\author{
Milica Gligorović, Nataša Buha, Bojan Dučić, Svetlana Kaljača \\ Univerzitet u Beogradu - Fakultet za specijalnu edukaciju i rehabilitaciju
}

\begin{abstract}
Rezime
Verbalna fluentnost je jedan od pokazatelja razvoja egzekutivnih funkcija i mentalnog leksikona. Cilj ovog rada je da utvrdi nivo fonološke i semantičke produktivnosti kod osoba sa umerenom intelektulnom ometenošću (IO).

Uzorak se sastoji od 58 osoba sa umerenom IO, uzrasta od 15 do 25 godina. Fonološka fluentnost procenjena je Testom kontrolisanih usmenih asocijacija, dok je semantička fluentnost procenjena Testom kategorijalnog imenovanja.

Postignuće na zadacima semantičke fluentnosti je bilo značajno bolje nego postignuće na zadacima fonološke fluentnosti. IQ je bio značajan faktor oba procenjena aspekta verbalne fluentnosti, ali je uzrast ispitanika imao veći pojedinačan uticaj na semantičku produktivnost i višu prediktivnu vrednost nego IQ.

Možemo zaključiti da sazrevanje i iskustvo predstavljju značajne faktore u formiranju leksičko-semantičke mreže, ali da ne doprinose značajno potencijalu osoba sa umerenom IO u generisanju i korišćenju nerutinskih strategija.

Programi intervencije bi trebalo da ponude širi repertoar strategija i kreativniji pristup u generisanju, organizovanju i korišćenju strategija.

Ključne reči: umerena intelektualna ometenost, verbalna fluentnost, fonološka fluentnost, semantička fluentnost, egzekutivne funkcije
\end{abstract}

Primljeno: 19.06.2018.

Prihvaćeno: 10.09.2018. 